\title{
The Moderating Effect of Leverage on the Relationship between Corporate Size and Audit Fees: Evidence from Jordanian Manufacturing Companies
}

\author{
AHMAD DAHIYAT \\ Department of Accounting/ Amman College, Al Balqa Applied University \\ JORDAN \\ AHMAD BAWANEH \\ Department of Accounting/ Amman College, Al Balqa Applied University \\ JORDAN
}

\begin{abstract}
The study aimed to examine the moderating role of leverage on the relationship between the size of listed Jordanian manufacturing companies and the audit fees over the period 2016-2020.

The study extracted the measures of variables from the annual report of manufacturing companies available on the Amman exchange website, it employs debt ratio to measure leverage, while issued capital and total assets were used to measure the size of the company, several statistics methods such as correlation and multiple linear regression and hierarchical regression were used to analyze the data and test the relations.

The results show a statistically significant impact of the size of the manufacturing company measured by capital and total assets on audit fees, furthermore, the leverage variable has modified and increase statistically the positive relationship between the size of the company and audit fees.
\end{abstract}

Keywords: Leverage, Size, Audit fees, Manufacturing companies, Jordan

Received: January 22, 2021. Revised: June 25, 2021. Accepted: June 30, 2021. Published: July 6, 2021.

\section{Introduction:}

Audit fees are the value of fees an auditor receives for a professional service based on service complexity, expertise level, and other factors. Audit fees are the fees that accounting firms and auditors earn to provide professional services. Audit fees can be described as the total of full fees that include both audits as well as nonaudit fees transferred to the audit firms [10]. Determining audit fees required mutual agreement between the audited company and the accounting firm. According to Hallak and Silva [14], auditors may charge lower fees to smaller leveraged firms and higher fees to large leverage firms as a premium of risks they take. Auditors evaluate several aspects of a company in different ways depending on its size. Arshad et al. [6] investigated that the audit department charged different audit fees depending on firm size, they also observed that large companies charge higher fees in exchange for the audit firm's services.

A company's size can be concluded by its sales, totals Assets, and capital size, and an average number of employees. Additionally, qualitative factors are considered, such as public firms and financial services firms do not qualify as microenterprise, small, or medium-sized firms. The optimal size of a firm in the manufacturing sector depends on the production technology, like capital intensity and scale economies [19]. Leverage can be defined as a ratio practice to measure how much a firm depends on debt to finance its assets. It is an investment strategy that explicitly uses borrowing and various financial tools for enhancing possible output on the funds invested. Similarly, leverage is also defined as the total value of liability that an organization utilizes for financing its assets. In other words, leverage is defined as loan utilization as a source of funds 
for investment purposes. Revenues from financial leverage are reinvested to earn more than the interest and expenses accrued on debt acquisition [8]. When a company uses fixed-rate funds, especially preferred capital and liabilities, shareholders' equity is called financial leverage [1].

The motivation of the study came when the researchers analyzed the cumulative data for Jordanian manufacturing companies, they found that debt ratio (debt to assets) increased materiality from 2016 to 2019, it reached respectively $(30.8 \%, 35.2 \%, 39.7 \%, 41.2 \%)$, also a debt to equity ratio increased from $45 \%$ in 2016 to $55 \%$ in 2017 to $66.5 \%$ in 2018 to $70.4 \%$ in 2019 , so researchers in the light of this trend increasing in leverage indicators, desire to study if the leverage will adjust the traditional relationship between the size of the company and the audit fees, this study expected to contribute by producing the leverage as a moderator variable of the relationship between the size of Jordanian manufacturing company and audit fees.

\section{Literature review and development of hypotheses:}

An audit is a systematic, structured process for obtaining an objective assessment of relevant evidentiary with assurances of economic events to ensure the degree of congruence between the assertions and the established standards and to deliver the results for the intended users, audit is done by an independent and competent person. [3].

The external auditor provides his services in return for fees from the auditee company, these fees depend on several factors, including the size of the audit firm [15]; [11], the reputation of the audit firm [31] and the time of the relationship between auditee and auditor [25] and the audit report type [30].

Several theories contribute in explain audit fees. At the top of these theories, is the theory of agency, which was discussed in the 1960s and 1970s. Agency theory is a theory of contractual relations, agency is defined as a contract in which a natural or legal person (or more than one person) uses the name of the principal or the principal the services of another person called the agent to perform a specific task in his name, which means delegating the decision-making to the agent [17]. Agency theory represents a conflict between principal and agent(s). Mishiel et al., [21] observed that the audit fees differ with firms due to agency theory conflict that arises in the firms because of excess free cash flow. Hence principal-agent conflict not only hampers organizational performance but impacts audit firm's decisions regarding audit fees. They charge different audit fees considering the prevailing situation of principal-agent conflict in the organization.

Many studies investigated the impact of corporate size and leverage on audit fees, but the researchers did not find any study that examines leverage as a moderator variable of the relationship between corporate size and audit fees.

\subsection{Firm size and Audit fees:}

Toto et al. [29] conducted a survey to get characteristics that affect companies' audit fees with good corporate governance. According to the survey, company size has a vital role in determining the audit fees that client firms pay to audit firms; however, there are few other critical aspects, like profits, the organizational complexity, and the subsidiaries' numbers were not considered crucial while determining audit fees by audit firms. Another study conducted by Yuniarti [33] concluded that when audit fees were tested individually as an independent variable, audit fees were found to be positively related to the size of an organization. Another study collected primary data for analysis. Group of certified accountant auditors registered by the Indonesian Accountants Association in 2009 picked a sample size of 27 companies and analyzed the primary data results. Suprapto and Suwardi [28] did not rely upon a single model for analysis but they adopted multiple models of regression for examining collected data. They choose firm size as an independent variable while auditing fee as a dependent variable. They found that firm size does not have a relation with audit fee. Hence audit fee is considered as free from firm size. At the same time, Yatim et al. [32] obtained a negative correlation between the firm 
size and the fee charged by the audit firm. The corporate size was significantly associated with audit fees [9]. An important positive association supports the view that big audit firms offer more high-quality services for an audit than smaller audit companies. The results of researchers [4] and [26] were consistent with the previous studies, where the auditee size has a statistically positive relationship with audit fees.

Habib et al, [12] examined the relationship between organizational capital and audit fees, the study applied on 40 countries spanning the period 2001-2017, the study concluded a linear relationship between capital and audit fees in companies that have business risks and agency problems, while Januarti \& Wiryaningrum [16] applied their study on Indonesian manufacturing companies and examined the determinants of audit fees, they concluded that the size and profitability, and complexity of the company have a positive relationship with audit fees.

Kiptum [18] studied the factors of audit fees, it is concluded that the size of the auditee, auditor familiarity and rank, Big 4 status, customer corporation, complication, and also audit report lag determined the audit fees.

\subsection{Leverage and audit fees:}

Mohammed et al. [22] conducted research and concluded that audit fees have a significant negative association with leverage. However, Monika et al. [24] in their study concluded that leverage has a positive relation with audit fees. Similarly, Zaman et al. [34] have observed a positive association with audit fees by using financial leverage as a risk indicator. They stated that auditors might charge a higher audit fee as a risk premium. Different studies provided different results in different scenarios. Hallak and Silva [14] obtained significant and negative relation between audit fees and leverage. Furthermore, based on an analytical study, it was concluded that there is a positive and significant association between leverage with anomalous audit fees [23]. It has been noticed that highly leveraged firm needs more effort for evaluating leveraged firms, thus creating a positive linkage between corporate audit fees and leverage [5]. The same result was obtained by Masoodul et al.,
[20], they supported a positive and significant linkage between audit fees and leverage.

Hossain \& Rama [7] concluded that estimated operating liability leverage has a significant impact on audit fees than contractual operating liability leverage.

According to the above, researchers formulate the following hypothesis:

HO.1: "There is no statistically significant impact at $(0.05 \geq \alpha)$ of company size measured by capital and total assets on audit fees."

HO.2: "There is no statistically significant impact at the $(0.05 \geq \alpha)$ level of leverage as a moderator role in the relationship between the size of the company measured by capital and audit fees."

HO.3: "There is no statistically significant impact at the level $(0.05 \geq \alpha)$ of leverage as a moderator role in the relationship between the size of the company measured by total assets and audit fees."

\section{Research Methodology:}

\subsection{Study Methods}

The study adopted the descriptive approach and the inferential approach as it is based on the interpretation of the investigated phenomenon relying on all facts and data and its classification. This approach is used to arrive at conclusions or generalizations about the phenomenon or problem, after processing and analyzing data [27].

\subsection{The population and sample of the study}

The study population was covered all the active manufacturing companies listed on the Amman Stock Exchange of (44) companies, and the study sample contains (39) companies that have financial statements during the study period. This study relied on secondary data derived from the annual reports, during the period of study from (2016-2020) that are available on the Amman stock exchange ASE website [2].

\subsection{Operationalization of variables}

Independent variable: The size of the company: measured by total assets and issued capital, to statistically processing the natural logarithm of variables was used. 
Dependent Variable: Audit fees: measured by the number of audit fees disclosed by the company in an annual report, to statistically processing the natural logarithm was used.

Moderator variable: leverage measured by debt ratio calculated by total liabilities/total assets.

\subsection{Multicollinearity Test}

Based on the results of table (1), which showed that the value of the (VIF) coefficient is less than
(10) as well as the (Tolerance) factor less than (1) and greater than (0.1) and that it is suitable for conducting statistical analysis, and there is no high correlation between them [13].

Table (1): VIF

\begin{tabular}{|l|l|l|}
\hline Variables & Tolerance & VIF \\
\hline Capital & 0.248 & 4.039 \\
\hline Total Assets & 0.248 & 4.039 \\
\hline
\end{tabular}

\section{Results:}

\subsection{Descriptive Results}

The natural Logarithm value was extracted for statistical analysis of (capital, total assets, and audit fees), and then the mean and standard deviation were extracted to be able to describe the study variables during the study period extending from 2016-2020 and shown in Table (2)

Table (2) Descriptive Results

\begin{tabular}{|l|l|l|l|l|l|}
\hline Variables & Minimum & Maximum & Mean & Std. Deviation & N \\
\hline Capital & 6 & 7.92 & 7.0906 & 0.46211 & 195 \\
\hline Total Assets & 6.54 & 9.07 & 7.4549 & 0.56274 & 195 \\
\hline Audit Fees & 2.70 & 4.90 & 4.0411 & 0.34226 & 195 \\
\hline Leverage & 0.03 & 0.96 & 0.3621 & 0.20817 & 195 \\
\hline
\end{tabular}

\subsection{The testing of the first hypothesis}

The first hypothesis of the study states HO.1: "There is no statistically significant impact at $(0.05 \geq \alpha)$ of company size measured by capital and total assets on audit fees."

This hypothesis was tested using (Multiple Linear Regression), and its results were as shown in Table (3).

Table (3) First hypothesis testing

\begin{tabular}{|l|l|l|}
\hline \multicolumn{2}{|l|}{ Model Summery } \\
\hline R & R2 & Adjusted R2 \\
\hline 0.624 & 0.389 & 0.382 \\
\hline
\end{tabular}

\begin{tabular}{|c|c|c|c|c|c|}
\hline \multicolumn{6}{|l|}{ ANOVA } \\
\hline Model & $\begin{array}{l}\text { Sum of } \\
\text { Squares }\end{array}$ & Df & Mean Square & $\mathrm{F}$ & Sig \\
\hline Regression & 8.835 & 2 & 4.418 & 61.061 & 0.00 \\
\hline Residual & 13.891 & 192 & 0.072 & & \\
\hline Total & 22.726 & 194 & & & \\
\hline
\end{tabular}




\begin{tabular}{|c|c|c|c|c|c|}
\hline \multicolumn{6}{|l|}{ Coefficient } \\
\hline & \multicolumn{2}{|c|}{ Unstandardized Coefficients } & $\begin{array}{l}\text { Standardized } \\
\text { Coefficients }\end{array}$ & \multirow[t]{2}{*}{$\mathrm{T}$} & \multirow{2}{*}{ Sig } \\
\hline Model & $\mathrm{B}$ & Std. Error & Beta & & \\
\hline Constant & 1.592 & 0.297 & & 5.362 & 0.00 \\
\hline Capital & 0.182 & 0.084 & 0.245 & 2.163 & 0.032 \\
\hline Total Assets & 0.501 & 0.069 & 0.824 & 7.269 & 0.00 \\
\hline \multicolumn{6}{|c|}{$3.00=(\mathrm{n}-1)-(\mathrm{K}-1)$ tabulated $\mathrm{F}$} \\
\hline & & & & $0=(n-$ & e" T value \\
\hline
\end{tabular}

Based on the above results, and through the value of (F.Sig) which is $(0.00)$ and the value of calculated (F) (61.061) and the value of the beta coefficient (of the capital) $(\beta=0.245)$, and the value of computed (T) (2.163) which is greater than its tabular value $(1.96)$ at the level of $(\mathrm{Sig}=0.032)$ which is significant. As for the value of the beta coefficient (for total assets), $(\beta=0.824)$, and that the value of (T) calculated (7.269) is greater than its tabular value at the level of $(\mathrm{Sig}=0.00)$

the null hypothesis (H0) is rejected, and we accept the alternative hypothesis (Ha), which says that there is a statistically significant impact at $(0.05 \geq \alpha)$ for the size of the company measured by capital and total assets on audit fees.

The value of $\mathrm{R}=(62.4 \%)$, indicates a strong relationship between the variables. The value of the determination coefficient $(\mathrm{R} 2=0.389)$ indicates that the two independent variables explained $(38.9 \%)$ of the variance in audit fees.

\subsection{The testing of the second hypothesis}

The second hypothesis of the study states HO.2: "There is no statistically significant impact at the $(0.05 \geq \alpha)$ level of leverage as a moderator role in the relationship between the size of the company measured by capital and audit fees."

"This hypothesis was tested using (Hierarchical Regression) test, and the results of the hypothesis test were as shown in Table (4).

Table (4) Second hypothesis testing

\begin{tabular}{|c|c|c|c|c|c|c|c|c|c|c|}
\hline \multirow{2}{*}{$\begin{array}{l}\text { Dependent } \\
\text { variable }\end{array}$} & \multirow{2}{*}{ Explanation } & \multicolumn{3}{|l|}{ 1Model } & \multicolumn{3}{|l|}{ 2Model } & \multicolumn{3}{|l|}{ 3Model } \\
\hline & & $\mathrm{T}$ & Beta & (sig) & $\mathrm{T}$ & Beta & (sig) & $\mathrm{T}$ & Beta & (sig) \\
\hline \multirow{9}{*}{$\underbrace{\infty}_{0}$} & Capital & 7.390 & 0.470 & 0.00 & 4.269 & 0.465 & 0.00 & 5.401 & .713 & .00 \\
\hline & Leverage & & & & 0.792 & 0.051 & 0.429 & 2.197 & 1.895 & 0.029 \\
\hline & Binary & & & & & & & 2.144 & & 0.033 \\
\hline & (R) & & & 0.470 & & & 0.472 & & & 0.491 \\
\hline & $\Delta(\mathrm{R})$ & & & & & & 0.002 & & & 0.021 \\
\hline & (R2) & & & 0.221 & & & 0.223 & & & 0.241 \\
\hline & $\Delta(\mathrm{R} 2)$ & & & & & & 0.002 & & & 0.02 \\
\hline & $\mathrm{F}$ & & & 54.617 & & & 27.569 & & & 20.256 \\
\hline & F Sig & & & 0.00 & & & 0.00 & & & 0.00 \\
\hline
\end{tabular}

"Table (4) indicates that in the first model, the impact of the size of the company measured by capital on the audit fees in the Jordanian manufacturing companies was studied, as it was proved that there is a significant impact of the size of the company measured by capital on the audit fees through the value of $F$ of $(54,617)$, which is a significant value at The level of significance $(\alpha \leq 0.05)$, and this result is supported by the value of (Beta) equal to (0.470), and the value of $\mathrm{T}$ which is equal to (7.390), which is significant at the level of significance $(\alpha \leq 0.05)$, and it appears from the first model that the size of the company measured 
by capital has been interpreted A percentage $(22.1 \%)$ of the variance in audit fees is based on the value of (R2). "In the second model, the leverage variable was entered and added to study, its impact on audit fees. 0.051 , and the $T$ value is equal to (0.792), which is not significant at the level of significance $(\alpha \leq 0.05)$ It appears from the second model that the leverage variable led to a very small increase in the value of (R2), which is $(0.2 \%)$ compared to the first model with the second model. In the third model, the formula for bilateral interaction between the size of the company measured by capital and leverage was introduced and added, and it was found that there is a significant impact of the bilateral interaction formula on the audit fees in manufacturing companies, as the value of $\mathrm{F}$ for the bilateral interaction formula was (20.256), the value of Bata (1.89) and the value of T. (2.144) and it is significant at the level of significance $(\alpha \leq 0.05)$, and the interpretation coefficient (R2) recorded a slight increase of (2\%) compared to the third model with the first model.

Accordingly, it can be said that the leverage variable has slightly modified the relationship between the size of the company measured by capital and audit fees.

\subsection{The testing of the Third hypothesis}

The hypothesis of the third study states HO.3: "There is no statistically significant impact at the level $(0.05 \geq \alpha)$ of leverage as a moderator role in the relationship between the size of the company measured by total assets and audit fees."

"This hypothesis was tested using (Hierarchical Regression) test, and the results of the hypothesis test were as shown in Table (5).

Table (5) Third hypothesis test

\begin{tabular}{|c|c|c|c|c|c|c|c|c|c|c|}
\hline \multirow{2}{*}{\begin{tabular}{|l} 
Dependent \\
variable \\
\end{tabular}} & \multirow{2}{*}{ Explanation } & \multicolumn{3}{|l|}{1 Model } & \multicolumn{3}{|l|}{ 2Model } & \multicolumn{3}{|l|}{ 3Model } \\
\hline & & $\mathrm{T}$ & Beta & (sig) & $\mathrm{T}$ & Beta & (sig) & $\mathrm{T}$ & Beta & (sig) \\
\hline \multirow{10}{*}{ 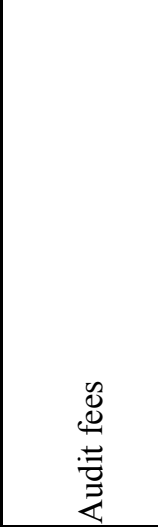 } & Total Assets & 10.735 & 0.611 & 0.00 & 10.587 & 0.608 & 0.00 & 8.265 & .987 & .00 \\
\hline & Leverage & & & & 0.440 & 0.025 & 0.660 & 3.609 & 2.919 & 0.00 \\
\hline & Binary & & & & & & & & & 0.00 \\
\hline & interaction & & & & & & & & & \\
\hline & (R) & & & 0.611 & & & 0.612 & & & 0.643 \\
\hline & $\Delta(\mathrm{R})$ & & & & & & 0.001 & & & 0.032 \\
\hline & (R2) & & & 0.374 & & & 0.375 & & & 0.414 \\
\hline & $\Delta(\mathrm{R} 2)$ & & & & & & 0.001 & & & 0.04 \\
\hline & $\mathrm{F}$ & & & 115.245 & & & 57.479 & & & 44.972 \\
\hline & F Sig & & & 0.00 & & & 0.00 & & & 0.00 \\
\hline
\end{tabular}

Table (5) indicates that in the first model, the impact of the size of the company measured by the total assets on the audit fees in the Jordanian manufacturing companies was studied, as it has been proven that there is a significant impact of the size of the company as measured by the total assets on the audit fees through the value of $F$ of $(115,245)$, which is a significant value at the level of The significance of $(\alpha \leq 0.05)$, and this result is supported by the value of (Beta) equal to (0.611), and the value of $\mathrm{T}$ which is equal to (10.735), which is significant at the level of significance $(\alpha \leq 0.05)$, and it appears from the first model that the size of the company measured by total assets has been interpreted as Its percentage is $(37.4 \%)$ of the variance in audit fees based on the value of (R2). "In the second model, the leverage variable was entered and added to study its impact on audit fees, and it was found that there is no significant effect of leverage through the value of (Beta) and the equal (0.025), and the value of $\mathrm{T}$ and the equal (0.440), which is not significant at the level of significance $(\alpha \leq 0.05)$

It appears from the second model that the entrance of the leverage led to a very small increase in the value of (R2), which amounted to $(0.1 \%)$ compared to the first model. In the third model, the formula for bilateral interaction between the size of the company measured by total assets and leverage was entered and added, and it was found that there is a significant effect of the bilateral interaction formula on the audit fees in 
manufacturing companies, as the value of $\mathrm{F}$ for the bilateral interaction formula was (44.972) and the value of Bata (2.969) and the value of T (3.585) which is significant at the level of significance $(\alpha \leq 0.05)$, and the interpretation coefficient (R2) recorded a slight increase of $(4 \%)$.

\section{Conclusions}

This paper has examined the impact of the size of Jordanian manufacturing companies on audit fees, in the existence of the leverage as a moderator variable over the period (2016-2020). The study concluded that there is a statistically significant impact for the size of the manufacturing company measured by capital and total assets on audit fees, this result which complied with many previous studies mentioned in the literature review, may justify the fact that the greater the size of the company, the greater the volume of work that is incumbent on the auditor, Accordingly, which leads companies to accept to pay high audit fees commensurate with their size.

Furthermore, the study indicated that leverage variable has modified and increased the strength of the relationship between the size of the company and audit fees, which mean that large manufacturing companies with high leverage are required to pay high audit fees, this may be justified that large companies with high leverage need efforts and intensive work, as well as high leverage, indicates high risk, so auditor may charge a higher fee as a premium of risks.

\section{References:}

[1] Adongo, Jackline. "The effect of financial leverage on Profitabilty and risk of firms listed at the Nairobi securities exchange." PhD diss., 2012.

[2] Amman stock exchange (2021), financial statements of manufacturing companies available on:

https://www.ase.com.jo/ar/disclosures

[3] Arens, Alvin A., Randal J. Elder, and Beasley Mark. Auditing and assurance services: an integrated approach. Boston: Prentice Hall, 2012.

[4] Aronmwan, Edosa, and Chinwuba Okafor. "Auditee characteristics and audit fees: An analysis of Nigerian quoted companies." Aronmwan, EJ, \& Okafor, CA (2015). Journal of Social and Management
Sciences 10, no. 2 (2014): 68-79.

[5] Arruñada, B. "La calidad de la auditoría." Incentivos privados y regulación. Marcial Pons, Madrid (1997).

[6] Arshad, Muhammad Aves, Rana Amir Satar, Mudassar Hussain, and Mohammad Akram Naseem. "Effect of audit on profitability: A study of cement listed firms, Pakistan." Global Journal of Management and Business Research 11, no. 9 (2011).

[7] Barua, Abhijit, Md Safayat Hossain, and Dasaratha V. Rama. "Financial versus operating liability leverage and audit fees." International Journal of Auditing 23, no. 2 (2019): 231-244.

[8] Cheng, Ming-Chang, and Zuwei-Ching Tzeng. "The effect of leverage on firm value and how the firm financial quality influence on this effect." World Journal of Management 3, no. 2 (2011): 30-53.

[9] Choi, Jong-Hag, Chansog Kim, Jeong-Bon Kim, and Yoonseok Zang. "Audit office size, audit quality, and audit pricing." Auditing: A Journal of practice \& theory 29, no. 1 (2010): 73-97.

[10] Frankel, Richard M., Marilyn F. Johnson, and Karen K. Nelson. "The relation between auditors' fees for nonaudit services and earnings management." The accounting review 77, no. s-1 (2002): 71-105.

[11] Glaum, Martin, and Donna L. Street. "Compliance with the disclosure requirements of Germany's new market: IAS versus US GAAP." Journal of International Financial Management \& Accounting 14, no. 1 (2003): 64-100.

[12] Habib, Ahsan, Mostafa Monzur Hasan, and Xuan Sean Sun. "Organization capital and audit fees around the world." International Journal of Auditing 24, no. 3 (2020): 321346.

[13] Hair, J, F, Black, W. C, Babin, B. J, Anderson, R, E, and Tatham, R, L.(2018). Multivariate Data Analysis (8thed): Cengage Learning EMEA. 
[14] Hallak, Rodrigo Telles Pires, and Andre Luiz Carvalhal da Silva. "Determinantes das despesas com serviços de auditoria e consultoria prestados pelo auditor independente no Brasil." Revista Contabilidade \& Finanças 23, no. 60 (2012): 223-231.

[15] Haniffa, Rozaini Mohd, and Terence E. Cooke. "Culture, corporate governance and disclosure in Malaysian corporations." Abacus 38, no. 3 (2002): 317-349.

[16] Januarti, Indira, and Mutiara Sukma Wiryaningrum. "The effect of size, profitability, risk, complexity, and independent audit committee on audit fee." Jurnal Dinamika Akuntansi 10, no. 2 (2018): 136-145.

[17] Jensen, Michael C., and William $\mathrm{H}$. Meckling. "Theory of the firm: Managerial behavior, agency costs and ownership structure." Journal of financial economics 3, no. 4 (1976): 305-360.

[18] Kiptum, Kimeli E. "Determinants of audit fees for listed firms in Kenya." $\mathrm{PhD}$ diss., University of Nairobi, 2013.

[19] Kumar, Krishna B., Raghuram G. Rajan, and Luigi Zingales "What Determines Firms Size?" University of Chicago. CRSP Working Paper No. 496. (2001).

[20] Masoodul Hassan, Saad Hassan, Asghar Iqbal and Muhammad Farooq Ahmed Khan, , Impact of Corporate Governance on Audit Fee: Empirical Evidence from Pakistan, World Applied Sciences Journal 30 (5): (2014), PP 645-651.

[21] Mishiel Suwaidan, Suzan Rasmi Abed, Sabeeka Melham , Audit Fees and Agency

Costs: An Empirical Examination of Companies Listed on the Amman Stock Exchange, Jordan Journal of Business Administration, Volume 11, No. 1, (2015) pp 215- 225.

[22] Mohammed Nma Ahmed, Okpanachi Joshua, and Momodu Mohammed, , audit fees and audit quality: a study of listed companies in the downstream sector of Nigerian petroleum industry, Humanities and Social Sciences Letters, Vol. 6, No. 2, (2018) pp. 59- 73.

[23] Mohsen Imeni \& Abbas Ali Daryaei, Audit
Fees: A Further Evidence of the Role of Financial and Operating Liability Leverage, Accounting and Auditing Review, 2020, Vol. 27, No.4, pp. 495522.

[24] Monika Causholli, Michael De Martinis, David Hay, W. Robert Knechel, , Audit Markets, Fees and Production: Towards An Integrated View of Empirical Audit Research, Journal of Accounting Literature, (2011)PP. 1-73.

[25] Okolie, Augustine O. "Auditor tenure, auditor independence and accrual-based earnings management of quoted companies in Nigeria." European Journal of accounting auditing and Finance Research 2, no. 2 (2014): 63-90.

[26] SANTHOSH, N., and R. SANKAR GANESH. "DETERMINANTS OF AUDIT FEES: EVIDENCE FROM COMPANIES LISTED IN THE INDUSTRIAL SECTOR OF MUSCAT SECURITIES MARKET." Journal of Critical Reviews 7, no. 3 (2020): 33-36.

[27] Sekaran, Uma, and Roger Bougie. Research methods for business: A skill building approach. John Wiley \& Sons, 2016.

[28] Suprapto, Eko, and Eko Suwardi. "The effect of audit partner rotation and audit firm's fee on audit quality." 8th Annual London Business Research (2013): 1-12.

[29] Rusmanto, Toto, and Stephanus Remond Waworuntu. "Factors influencing audit fee in Indonesian Publicly Listed Companies applying GCG." Procedia-Social and Behavioral Sciences 172 (2015): 63-67.

[30] Verbruggen, Sandra, Johan Christiaens, Anne-Mie Reheul, and Tom Van Caneghem. "Analysis of audit fees for nonprofits: Resource dependence and agency theory approaches." Nonprofit and Voluntary Sector Quarterly 44, no. 4 (2015): 734-754.

[31] Wang, Kun, Zahid Iqbal, and L. Murphy Smith. "Auditor market share and industry specialization of non-big 4 firms." Journal of Accounting and Finance 11, no. 2 (2011): 107-127.

[32] Yatim, P., Kent, P., \& Clarkson, P. Governance structures, ethnicity, and audit fees of Malaysian listed firms. 
Managerial Auditing Journal 21 (7). (2006). PP 757- 782.

[33] Yuniarti, Rita. Audit firm size, audit fee and audit quality. Journal of Global Management, 2(1), (2011).PP 84-97.

[34] Zaman, Mahbub, Mohammed Hudaib, and Roszaini Haniffa. "Corporate governance quality, audit fees and non- audit services fees." Journal of Business Finance \& Accounting 38, no. 1- 2 (2011): 165-197.

\section{Contribution of individual authors to the creation of a scientific article (ghostwriting policy)}

Ahmad Dahiyat was responsible for the introduction and theoretical aspects of the study, and the discussion and conclusion and recommendations.

Ahmad Bawaneh was responsible for extracting and preparing the financial measures of the study and was responsible of Statistics.

Follow:

www.wseas.org/multimedia/contributor-role-

instruction.pdf

Creative Commons Attribution License

4.0 (Attribution 4.0 International , CC

BY 4.0)

This article is published under the terms of the Creative Commons Attribution License 4.0

https://creativecommons.org/licenses/by/4.0/d eed.en US 